\title{
Assessing the tolerance of immobilized laccase from a salt-tolerant strain of Trichoderma viride Pers NFCCI-2745 to heavy metal ions, detergents and copper chelating agents
}

\author{
L. M. Divya · G. K. Prasanth · C. Sadasivan
}

Received: 28 May 2013/Revised: 2 October 2014 / Accepted: 22 October 2014/Published online: 7 November 2014

(C) Islamic Azad University (IAU) 2014

\begin{abstract}
The biotreatment of industrial effluents that contain heavy metals, detergents and metal chelating agents represents a great concern to industries as these compounds are either toxic to microbes or they act as noncompetitive inhibitors/denaturing agents for several enzymes. So, it is essential to know the effect of various agents usually present in the treatment plant on activity of the enzyme, for extending its applications in in situ treatment processes. This study describes the immobilization conditions of laccase and analysis of the sensitivity of immobilized laccase from Trichoderma viride Pers NFCCI-2745 to heavy metals, detergent and copper chelating agents. The concentrations and combinations of cations influenced the activity of immobilized enzyme and its yield. The immobilized $\mathrm{Cu}-\mathrm{Ba}$ alginate enzyme showed comparatively higher activity compared to the $\mathrm{Cu}$-alginate enzyme. Most of the metal ions tested enhanced laccase activity at lower concentration. Immobilized laccase retained more than $70 \%$ of its activity even in the presence of $20 \mathrm{mM}$ copper chelating agents like EDTA and sodium thioglycolic acid. Sodium azide, on the other hand, inhibited $80 \%$ of the activity of all the beads even at a very low concentration of $0.5 \mathrm{mM}$. $\mathrm{Cu}-\mathrm{Ba}$ and $\mathrm{Cu}-\mathrm{Ni}$ alginate enzyme exhibited comparatively higher tolerance than $\mathrm{Cu}$ alginate beads to EDTA and sodium thioglycolate. Tween 20 and cetyl trimethyl ammonium bromide significantly increased the activity of all the beads. These properties of the immobilized laccase may be aptly considered and suitably utilized in treating phenolic effluents that may
\end{abstract}

L. M. Divya · G. K. Prasanth · C. Sadasivan ( $₫)$ Department of Biotechnology and Microbiology, Kannur University, Thalassery campus, Palayad P.O, Kannur 670661, Kerala, India e-mail: csadasivan@gmail.com contain heavy metals, detergents and certain copper chelating agents which may otherwise pose a threat to enzymatic activity.

Keywords Copper chelating - Heavy metals · Immobilization - Laccase - Trichoderma sp.

\section{Introduction}

Laccases (benzenediol oxygen oxidoreductases, EC 1.10.3.2) are considered as one of the most promising enzymes for future industrial applications (Xu et al. 2000). Due to their low substrate specificity and strong oxidative abilities, laccases have a number of industrial applications such as textile dye bleaching, enzymatic conversion of chemical intermediates, biopulping, prevention of wine decolouration, the production of valuable compounds from lignin, soil bioremediation and biodegradation of environmental phenolic pollutants and removal of endocrine disruptors (Abadulla et al. 2000; Cuoto and Herrera 2006; Divya et al. 2013a, b, c; Fukuda et al. 2001; Hemmat and Mazaheriassadi 2013; Mayer and Staples 2002; Nayanashree and Thippeswamy 2014; Rama et al. 1998; Sole et al. 2012; Tyagi et al. 2014). The ideal laccases for industrial use would exhibit stability at high temperature and $\mathrm{pH}$ conditions (Niladevi et al. 2008).

In order to extend the applications of laccase more efficiently in industrial processes and biotreatment, their immobilization is necessary as it will potentiate its biochemical stability and reusability (Couto et al. 2004; Delanoy et al. 2005; Peralta-Zamora et al. 2003). Laccase is a copper-dependent enzyme, and the enzyme immobilized in copper alginate is likely to retain more activity than laccase 
immobilized using other methods. Laccase of Pleurotus ostreatus and Ganoderma $s p$ were successfully entrapped in copper alginate beads and decolorized some synthetic dyes efficiently (Palmieri et al. 2000; Teerapatsakul et al. 2008). The biotreatment of industrial effluents that contain heavy metals, detergents, copper chelating agents and phenolic compounds arises a great concern to industries as these compounds are either toxic to microbes or they act as non-competitive inhibitors or as denaturing agents for several enzymes. Studies describing the effect of metal ions, surfactants and copper chelating agents have not been studied in detail. A recent study has described the effect of a non-ionic surfactant, merpol, on decolorization of dyes by immobilized laccase (Champagne et al. 2013), but not about anionic or cationic surfactants. So, it is essential to know the effect of various agents usually present in the treatment plant on activity of the enzyme, for extending its applications in in situ treatment processes. Thus, this study has been designed to immobilize laccase and to investigate the effects of heavy metal ions, copper chelating agents and detergents on the potential of immobilized laccase. Laccase-producing phenol and salt-tolerant strain of Trichoderma viride Pers NFCCI-2745 used for the study were isolated from the coconut husk retting ground, a highly phenolic and saline region in the back waters of Palayad region, near Kannur University, Thalassery campus, North Kerala, during December 2009, and the entire immobilization study was carried out at the Department of Biotechnology and Microbiology, Kannur University during June 2012 to December 2012.

\section{Materials and methods}

\section{Chemicals and enzyme}

Sodium alginate was purchased from Himedia, India. All other metal salts and chemicals used were of analytical grade and obtained from Himedia and Merck, India.

The laccase-producing salt and phenol-tolerant fungi, $T$. viride Pers NFCCI-2745 isolated from the coconut husk retting pile, a highly saline and phenolic rich environment in the estuarine waters of North Kerala, India, were used as a source for laccase. Laccase being an extracellular enzyme may also have the potential to tolerate this harsh environmental condition. So selecting such strain may be advantageous to treat the phenolic effluents like textile and coir industry which are highly phenolic and saline in nature. Identification of the strain was done based on Inter transcribed spacer (ITS) sequencing of rDNA of fungal genome from the National Fungal Culture Collection of India (NFCCI), Pune, India, and the strain was deposited under the accession number: NFCCI-2745, and the ITS sequence of the fungus deposited at GenBank, NCBI under the accession ID: KF638399.1. For immobilization of extracellular laccase, Trichoderma sp NFCCI-2745 was cultivated on a defined medium (Divya et al. 2013c) with composition (in $\mathrm{gL}^{-1}$ ): glucose-10; peptone-1.0; yeast extract -0.5 using $0.3 \mathrm{mM}$ copper to stimulate laccase formation. Mycelia were separated by centrifugation (20 min; 10,000g) after $96 \mathrm{~h}$ cultivation when laccase activity reached its maximum and vacuum filtered with $0.22 \mu \mathrm{m}$ membrane (PVDF Durapore GV $0.22 \mu \mathrm{m}$, Millipore). Laccase activity was determined by the oxidation of guaiacol $(20 \mathrm{mM})$ buffered with $50 \mathrm{mM}$ sodium phosphate buffer of $\mathrm{pH} 6.5$, temperature $-32{ }^{\circ} \mathrm{C}$ at $460 \mathrm{~nm}$ (Divya et al. 2013c).

\section{Enzyme immobilization}

Sodium alginate powder $(3 \% \mathrm{w} / \mathrm{v})$ was added to the crude enzyme solution $(10 \mathrm{U} / \mathrm{mL})$, and then, the mixture was stirred thoroughly to ensure complete mixing for $20 \mathrm{~min}$. The mixture was added drop-by-drop by means of a peristaltic pump equipped with a syringe into $50 \mathrm{~mL}$ of $\mathrm{CuSO}_{4}$ used as cross-linker solutions, dissolved in distilled water (flow rate $10 \mathrm{~mL} \mathrm{~min}^{-1}$ ). Experiments were conducted in triplicate with different concentrations of $\mathrm{CuSO}_{4}$ solutions ranging between 50 and $300 \mathrm{mM}(50,75,100,125$ up to $300 \mathrm{mM}$ ); the corresponding metal alginate beads were formed. After $30 \mathrm{~min}$, the spherical beads were washed with distilled water. The same procedure was used to study effects of different concentrations of cross-linking agents such as $\mathrm{CaCl}_{2}, \mathrm{ZnSO}_{4}, \mathrm{SrCl}_{2}, \mathrm{BaCl}_{2}, \mathrm{NiCl}_{2}, \mathrm{MgCl}_{2}$ and $\mathrm{HgCl}_{2}$ and the combination of each ions with $\mathrm{CuSO}_{4}$, each of $0-75 \mathrm{mM} \quad(0 \mathrm{mM}$ cation: $75 \mathrm{mM} \mathrm{Cu}, 25 \mathrm{mM}$ cation: $50 \mathrm{mM} \mathrm{Cu}, 37.5 \mathrm{mM}$ cation: $37.5 \mathrm{mM} \mathrm{Cu}, 50 \mathrm{mM}$ cation: $25 \mathrm{mM} \mathrm{Cu}$ and $75 \mathrm{mM}$ cation: $0 \mathrm{mM} \mathrm{Cu}$,) to get a final concentration of $75 \mathrm{mM}$. The immobilization yield was determined as residual laccase activity found after dissolution of beads (by incubation in $50 \mathrm{mM}$ sodium phosphate buffer of $\mathrm{pH} 6.5$ temperature $-32{ }^{\circ} \mathrm{C}$ for $15 \mathrm{~min}$ ) compared with the laccase activity of free soluble enzyme. The beads which gave maximum enzyme activity were selected for further experiments. The selected enzyme alginate beads were further used for determining the $\mathrm{pH}$ and temperature optima and analyzing the tolerance of immobilized laccase to heavy metal ions, detergent and copper chelating agents.

Optima $\mathrm{pH}$ and temperature of immobilized alginate laccase

$\mathrm{Cu}$-alginate beads, $\mathrm{Cu}-\mathrm{Ba}$ alginate beads, $\mathrm{Cu}-\mathrm{Ni}$ alginate beads and $\mathrm{Cu}-\mathrm{Sr}$ alginate beads were selected for the following study; $\mathrm{pH}$ and temperature optima, and stability and 
Table 1 Buffers used for optimization study

\begin{tabular}{ll}
\hline Buffers & $\mathrm{pH}$ \\
\hline Glycine- $\mathrm{HCl}$ & 2.5 and 3 \\
Sodium acetate & $3.5,4,4.5,5,5.5$ and 6 \\
Sodium phosphate & 6 and 6.5 \\
Tris- $\mathrm{HCl}$ & $7.0,7.5,8.0$ and 9.0 \\
Glycine- $\mathrm{NaOH}$ & 9,10 and 11 \\
\hline
\end{tabular}

assessing their potential in treating phenolic industrial effluent. All the selected beads were prepared in crosslinker solution of $75 \mathrm{mM}$ of respective cationic solution. For combination beads, the $\mathrm{Cu}: \mathrm{Ba} / \mathrm{Sr} / \mathrm{Ni}$ which were maintained in the ratio $7.5: 2.5$, respectively, to get a final concentration of $75 \mathrm{mM}$ cross-linker solution gave maximum laccase activity and hence selected for further experiments.

The immobilized enzymes ( 15 beads/tube) were assayed for laccase activity using $20 \mathrm{mM}$ guaiacol as substrate in $100 \mathrm{mM}$ buffers, $\mathrm{pH}$ ranging from 2.0 to 11 at $32{ }^{\circ} \mathrm{C}$ for $10 \mathrm{~min}$ in comparison with free soluble enzyme. $\mathrm{pH}$ optima was studied using the buffers $(100 \mathrm{mM})$ given in Table 1 .

For optimum temperature of each immobilized enzymes, the assay reactions were performed in $50 \mathrm{mM}$ sodium phosphate buffer, $\mathrm{pH} 6.5$ at various temperatures ranging from 30 to $90{ }^{\circ} \mathrm{C}$ for $10 \mathrm{~min}$ with $20 \mathrm{mM}$ guaiacol substrate.

Effect of metal ions on the activity of immobilized laccase

Immobilized laccase was incubated for $10 \mathrm{~min}$ with 0-25 mM metal ion solution and then assayed for laccase activity at standard assay condition. The metal chlorides used in the present study are: $\mathrm{Hg}^{2+}, \mathrm{Cd}^{2+}, \mathrm{Ba}^{2+}, \mathrm{Sr}^{2+}$, $\mathrm{Ni}^{2+}, \mathrm{Mg}^{2+}$ and $\mathrm{Ca}^{2+}$.

Effect of copper chelating agents on the activity of immobilized laccase

Immobilized laccase was incubated for $10 \mathrm{~min}$ with different concentration of copper chelating agents ranging between 1 and $10 \mathrm{mM}$ and then assayed for laccase activity at standard assay conditions. The copper chelating agents used in the present study are: EDTA, Sodium thioglycolic acid and Sodium azide. Each experiment was conducted in triplicate.

Effect of detergents on the activity of immobilized laccase

Immobilized laccase was incubated for $10 \mathrm{~min}$ with different concentration of detergent solutions, ranging between 0.1 and $10 \mathrm{mM}$ and then assayed for laccase activity at standard assay condition. The detergents used in the present study are: sodium dodecyl sulfate (SDS), an anionic detergent; cetyl trimethyl ammonium bromide (CTAB), a cationic detergent; and Tween 20, non-ionic detergent. Each experiment was conducted in triplicate.

Statistics

All experiments were repeated at least three times, and each value was measured in triplicate. The results are expressed as means \pm SDs. To analyze the statistical significance among the different experimental conditions, two-factor ANOVA with a Bonferroni post-test multiple comparisons and a two-tailed paired Student's $t$ test was preformed at $95 \%$ confidence interval using GraphPad Prism software.

\section{Results and discussion}

In this study, crude laccase enzyme secreted by a salttolerant strain of $T$. viride NFCCI-2745 isolated from coconut husk retting ground, a highly saline and phenolic rich zone, in the backwaters of Kerala was investigated for alginate entrapment with different cation types and their combinations. The cation concentrations on enzyme entrapment were optimized. The effects of $\mathrm{pH}$ and temperature, heavy metal ions, detergents and copper chelating agents on catalytic reaction of the immobilized enzymes were also studied.

Enzyme immobilization on alginate

Different kinds of alginate beads were used to entrap laccase from T. viride NFCCI-2745. Spherical round beads of $2 \mathrm{~mm}$ diameter with laccase activity were formed when entrapped in $\mathrm{Cu}-\mathrm{Ba}, \mathrm{Cu}-\mathrm{Sr}$ and $\mathrm{Cu}$-alginate beads. While $\mathrm{Zn}$ and $\mathrm{Cu}-\mathrm{Ni}$ alginate entrapment produced slightly irregular beads, $\mathrm{Sr}$ and $\mathrm{Ba}$ alginate produced higly irregular shaped beads, with comparatively lower laccase activity and $\mathrm{Ni}$-alginate entrapment produced string-like alginate laccase, with detectable enzymatic activity. No beads were formed for $\mathrm{MgSO}_{4}$ and $\mathrm{HgCl}_{2}$, when used as cross-linkers either alone or in combination with $\mathrm{CuSO}_{4}$. Laccase is a copper-dependent enzyme, and thus, $\mathrm{Cu}$ ions play an important role in maintaining the catalytic mechanism of laccase (Palmieri et al. 1997; Duran et al. 2002). It was earlier reported that $\mathrm{Cu}$-alginate laccase from Trametes villosa gave better immobilization yield than $\mathrm{Ca}$-alginate for laccase (Brandi et al. 2006). Our results support the earlier findings, and in addition, the combinations of $\mathrm{Cu}$ with other cations also gave promising results. 

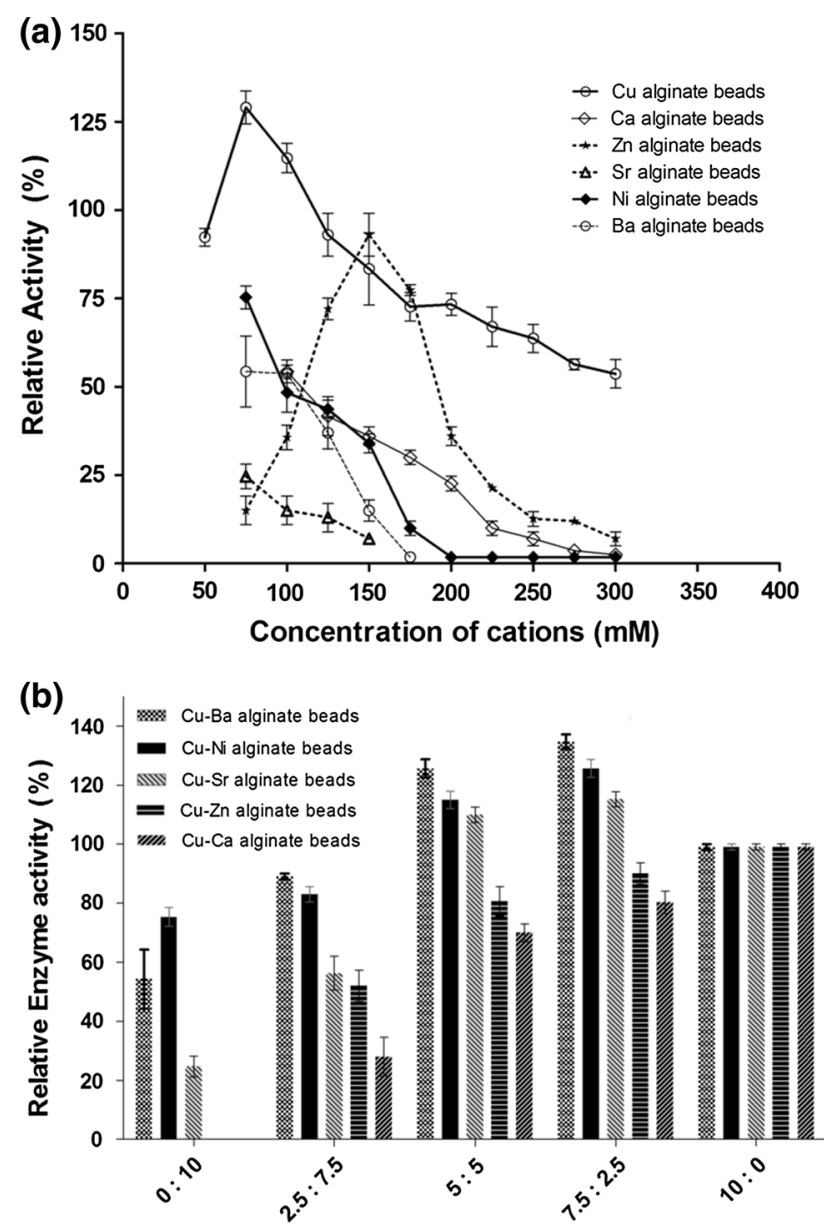

Ratio of $\mathrm{Cu}$ : Cations in $75 \mathrm{mM}$ crosslinker solution

Fig. 1 Alginate entrapment of laccase from T. viride NFCCI-2745. a Different kinds of alginate beads. b Ratio of $\mathrm{Cu}^{2+}$ in the combination

The enzyme activity of the immobilized beads is plotted in relative percentage taking the activity of free enzyme $(10 \mathrm{U} / \mathrm{mL})$ as $100 \%$. Of the six metals tested as shown in Fig. 1a, the $\mathrm{Cu}$-alginate beads at $75 \mathrm{mM}$ concentration gave highest activity $(P$ value $<0.001)$ followed by $150 \mathrm{mM} \mathrm{Zn}$-alginate beads, $75 \mathrm{mM} \mathrm{Ni}$-alginate beads and $100 \mathrm{mM}$ Ca-alginate beads which showed significantly lower activity compared to $\mathrm{Cu}$-alginate beads. Increasing the concentration of $\mathrm{CuSO}_{4}$ and other cationic solutions had a negative effect on immobilization yield. It was earlier reported that increasing of the alginate or $\mathrm{CuSO}_{4}$ concentration limits the substrate transfer into the alginate bead (Knezevic et al. 2002; Teerapatsakul et al. 2008). Also in the immobilisation of Candida rugosa lipase, increasing the alginate concentration decreased immobilisation yield, but increasing the concentration of the cross-linking agent,
Table 2 Two-factor ANOVA with Bonferroni's post-test indicating the significance of ratio of $\mathrm{Cu}$ in combination with $\mathrm{Ba}, \mathrm{Ni}$ and $\mathrm{Sr}$

\begin{tabular}{lllll}
\hline Cu-alginate & Ratio of $\mathrm{Cu}$ & Difference & $T$ & $P$ value \\
\hline $\mathrm{Cu}-\mathrm{Ba}$ & 5.000 & 40.33 & 13.57 & $<0.001$ \\
& 7.500 & 42.07 & 14.16 & $<0.001$ \\
$\mathrm{Cu}-\mathrm{Ni}$ & 5.000 & 29.67 & 9.985 & $<0.001$ \\
& 7.500 & 33.07 & 11.13 & $<0.001$ \\
$\mathrm{Cu}-\mathrm{Sr}$ & 5.000 & 24.67 & 8.302 & $<0.001$ \\
& 7.500 & 22.73 & 7.651 & $<0.001$ \\
\hline
\end{tabular}

$\mathrm{CaCl}_{2}$ had little effect (Won et al. 2005). Since $75 \mathrm{mM}$ $\mathrm{CuSO}_{4}$ gave maximum activity, all the beads were prepared in cross-linker solution of $75 \mathrm{mM}$ of respective cationic solution for the experiments conducted thereafter.

As shown in Fig. 1b, beads where $\mathrm{Cu}$ is in combination with $\mathrm{Ba}, \mathrm{Ni}$ and $\mathrm{Sr}$ gave higher activity than $\mathrm{Cu}$-alginate beads, and combination of $\mathrm{Cu}$ with $\mathrm{Zn} / \mathrm{Ca}$ produced beads with much lesser activity than $\mathrm{Cu}$-alginate. The results of the statistical analysis using two-factor ANOVA with Bonferroni post-tests indicates that $\mathrm{Cu}$ in combination with $\mathrm{Ba}, \mathrm{Ni}$ and $\mathrm{Sr}$ were significant in the ratio from 0.5 to 7.5 $(P$ value $<0.001)$ data shown in Table $2 . \mathrm{Cu}: \mathrm{Ba} / \mathrm{Sr} / \mathrm{Ni}$ which were maintained in the ratio 7.5:2.5, respectively, to get a final concentration of $75 \mathrm{mM}$ cross-linker solution gave higher immobilization yield than $\mathrm{Cu}$-alginate beads (10:0), and beads prepared with $\mathrm{Cu}: \mathrm{Zn} / \mathrm{Ca}$ gave least activity (Fig. 1b). Increasing the concentrations of other cations in combination with $\mathrm{Cu}$ above $25 \mathrm{mM}$ decreased the activity of immobilized laccase for all the metals/cations tested. In other words, decreasing the concentrations of $\mathrm{Cu}$ below $50 \mathrm{mM}$ in the combination beads decreased the activity of immobilized laccase for all the metals/cations tested. $\mathrm{Cu}$-alginate beads retained $95 \%$ of the initial activity even after storing for 7 days at $4{ }^{\circ} \mathrm{C}$ (data not shown). Stimulation of laccase activity upon the addition of $\mathrm{Cu}^{2+}$ ions was reported in P. ostreatus and Ganoderma sp (Baldrian and Gabriel 2002; Teerapatsakul et al. 2008). To our knowledge, this is the first study describing the immobilization of laccase with different cations and their combinations.

$\mathrm{pH}$ and temperature optima of immobilized laccase

$\mathrm{Cu}$-alginate beads, $\mathrm{Cu}-\mathrm{Ba}$ alginate beads, $\mathrm{Cu}-\mathrm{Ni}$ alginate beads and $\mathrm{Cu}-\mathrm{Sr}$ alginate beads which showed maximum laccase activity were selected for further studies. In the case of combination beads, the $\mathrm{Cu}: \mathrm{Ba} / \mathrm{Sr} / \mathrm{Ni}$ which were maintained in the ratio $7.5: 2.5$, respectively, to get a final 

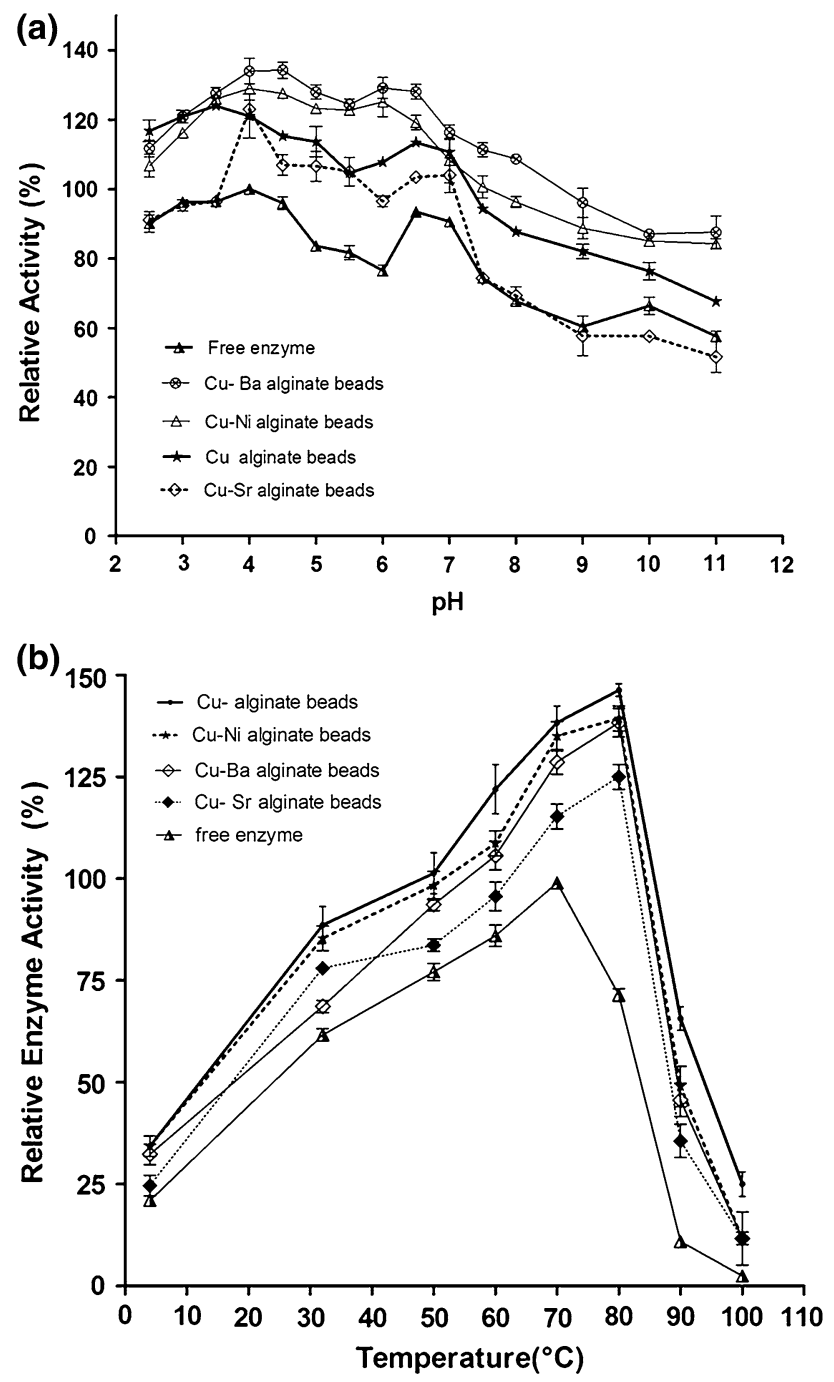

Fig. $2 \mathrm{pH}$ and temperature optima of immobilized laccase. a pH Optima. b Temperature optima

concentration of $75 \mathrm{mM}$ cross-linker solution exhibited maximum activity.

All the tested immobilized enzymes displayed almost similar pattern of $\mathrm{pH}$ effects compared to that of the free enzyme. The immobilized enzyme was most active in a broad $\mathrm{pH}$ range of 2.5-7.0 with maximum activities at $\mathrm{pH}$ 4.0 and pH 6.5 (Fig. 2a). The two peaks observed for the enzyme activity may be due to the presence of laccase isozymes in the crude culture filtrate. The alginate is able to absorb $\mathrm{H}^{+}$within beads that resulted in decreasing the $\mathrm{H}^{+}$ outside beads and shifting the optimum pH (Lu et al. 2007; Tischer and Kasche 1999; Yinghui et al. 2002). This problem could be resolved by using a solution with a high ionic strength (Tischer and Kasche 1999). Thus, in contrast to earlier reports, no significant shift in the optimum $\mathrm{pH}$ was observed for immobilized laccase.
Table 3 Values of two-tailed paired $t$ test compared at $95 \%$ confidence interval between free enzymes and different metal alginates

\begin{tabular}{llll}
\hline Metal alginate & $d f$ & $\mathrm{~T}$ & $P$ value \\
\hline $\mathrm{Cu}$ & 7 & 5.174 & 0.0013 \\
$\mathrm{Cu}-\mathrm{Ba}$ & 7 & 3.493 & 0.0101 \\
$\mathrm{Cu}-\mathrm{Ni}$ & 7 & 4.421 & 0.0031 \\
$\mathrm{Cu}-\mathrm{Sr}$ & 7 & 3.091 & 0.0175 \\
\hline
\end{tabular}

Study on the effect of temperature on laccase activity of the immobilized alginate enzymes namely $\mathrm{Cu}$-alginate beads, $\mathrm{Cu}-\mathrm{Ba}$ alginate beads, $\mathrm{Cu}-\mathrm{Ni}$ alginate beads and $\mathrm{Cu}-\mathrm{Sr}$ alginate beads compared to the free enzyme, however, revealed significant differences $(P<0.05)$ data shown in Table 3. All the immobilized enzymes analyzed as shown in (Fig. 2b) exhibited higher temperature optima than that of free enzyme $P$ value $<0.001$. The $\mathrm{Cu}-, \mathrm{Cu}-\mathrm{Sr}$, $\mathrm{Cu}-\mathrm{Ni}$ and $\mathrm{Cu}-\mathrm{Ba}$ alginate enzymes had optimum temperature at $80^{\circ} \mathrm{C}$, whereas the temperature optimum for free enzyme was $70{ }^{\circ} \mathrm{C}$. A similar effect of rise in the optimum temperature by $10{ }^{\circ} \mathrm{C}$ was reported for lipase in gray mullet and laccase of Lentinus polychrous, respectively (Aryee and Simpson 2012; Phetsom et al. 2009).

Effect of metal ions, copper chelating agents and detergents on the activity of immobilized laccase

The effects of various metal ions, copper chelating agents and detergents on the enzymatic activity of immobilized laccase were not previously examined. In the present study, $\mathrm{Cu}$-alginate beads, $\mathrm{Cu}-\mathrm{Ba}$ alginate beads, $\mathrm{Cu}-\mathrm{Ni}$ alginate beads and $\mathrm{Cu}-\mathrm{Sr}$ alginate beads were selected for assessing their tolerance to heavy metal ions, copper chelating agents and detergents. All the selected beads were prepared in a cross-linker solution of $75 \mathrm{mM}$ of a respective cationic solution. In the case of combination beads, the $\mathrm{Cu}: \mathrm{Ba} / \mathrm{Sr} / \mathrm{Ni}$ were maintained in the ratio 7.5:2.5, respectively, to get a final concentration of $75 \mathrm{mM}$ cross-linker solution.

\section{Effect of metal ions}

Metal ions can act as non-competitive inhibitors of enzymes; their presence in treatment plants usually poses a threat to biotreatment processes. So, the effect of metal ions on the activity of immobilized laccase was checked. To calculate relative activities, the actual activity in the absence of these agents under the same experimental conditions was set to $100 \%$. All the immobilized enzymes displayed almost a similar pattern of activity with metal ions (Fig. 3). The immobilized laccases exhibited an increased activity in the presence of metal 

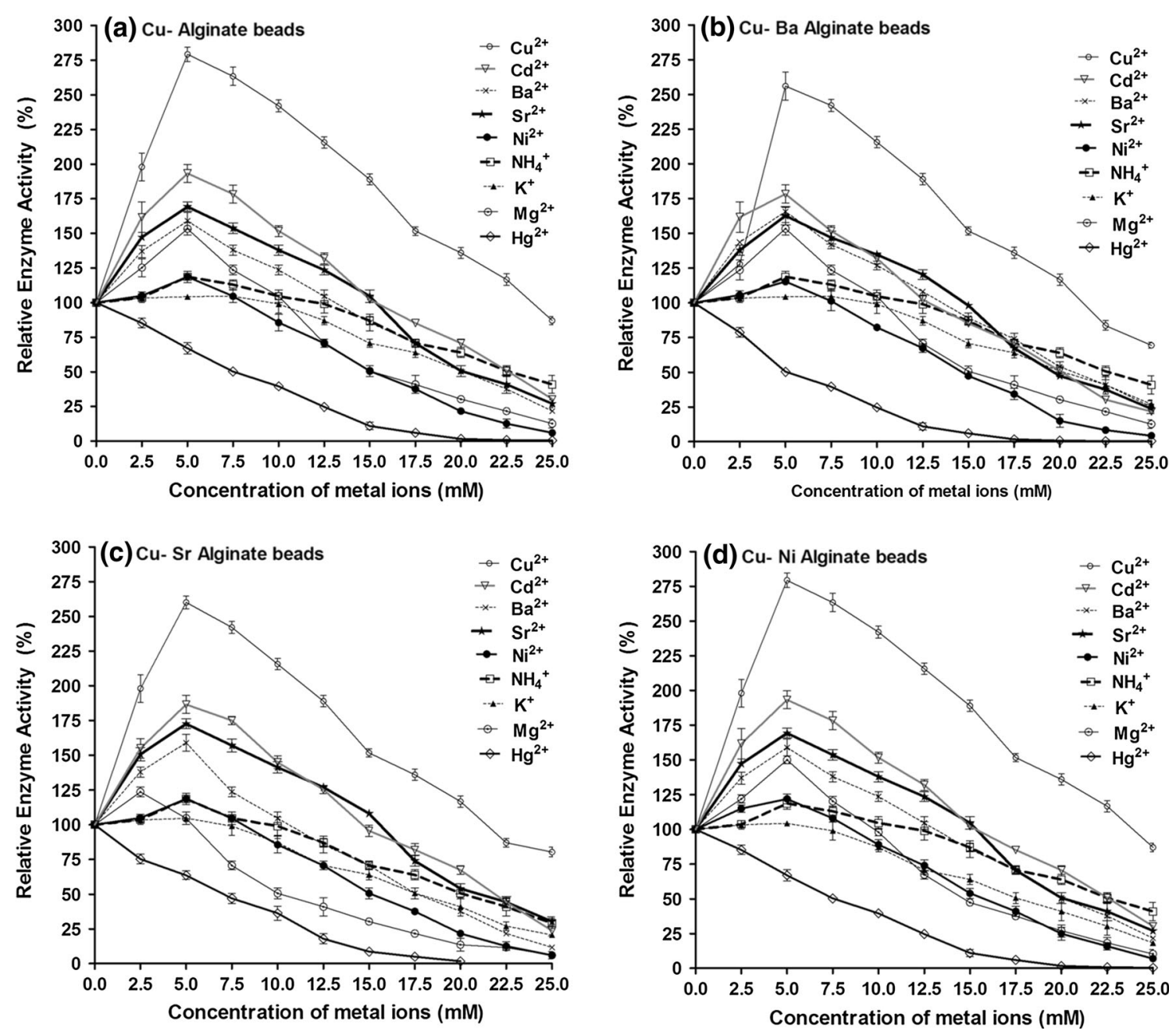

Fig. 3 Tolerance of immobilized laccase to metal ions. a Cu-alginate beads. b $\mathrm{Cu}-\mathrm{Ba}$ alginate beads. $\mathbf{c} \mathrm{Cu}-\mathrm{Sr}$ alginate beads. $\mathbf{d} \mathrm{Cu}-\mathrm{Ni}$ alginate beads

ions at lower concentrations with maximum activity at $5 \mathrm{~mm}$ concentration of metal ions. $\mathrm{Cu}^{2+}$ at $5 \mathrm{mM}$ concentration induced laccase activity almost three times, and Cadmium also enhanced the activity almost two times. This was followed by $\mathrm{Sr}^{2+}, \mathrm{Ba}^{2+}$ and $\mathrm{Mg}^{2+}$. With increase in the concentration of metal ions, laccase activity reduced gradually, but retained $50-70 \%$ of its activity even at $20 \mathrm{mM}$ concentrations of all the metal ions tested except for $\mathrm{Hg}^{2+}$. With further increase in the metal ion concentration above $20 \mathrm{mM}$, laccase activity decreased, but had detectable activity even at $25 \mathrm{mM}$. Copper and cadmium was also reported to increase the laccase activity in P. ostreatus (Baldrian et al. 2000). Baldrian has discussed the sensitivity of laccases toward heavy metal ions as well (Baldrian 2006). In agreement to this, we observed that $\mathrm{Hg}^{2+}$ inhibited laccase activity even at a very low concentration of $0.5 \mathrm{mM}$. In addition to monovalent salt, $\mathrm{K}^{+}$didn't exert any significant effect on laccase activity. Recent study on purified laccase from Ganoderma sp. has shown maximum inhibition of laccase with $\mathrm{CoCl}_{2}$ and $\mathrm{HgCl}_{2}$ and stability in presence of $\mathrm{CaCl}_{2}$, $\mathrm{MnSO}_{4}, \mathrm{FeCl}_{3}, \mathrm{ZnSO}_{4}$ and $\mathrm{BaCl}_{2}(0.5-3 \mathrm{mM})$ with a significant inhibition only at $10 \mathrm{mM}$ of the metal ions (Sharma et al. 2013). However, the effect of metal ions on immobilized laccase was not reported earlier. This study for the first time demonstrates the effect of metal ions on immobilized laccase. The stability exhibited by the immobilized laccase toward high concentrations of vari- 

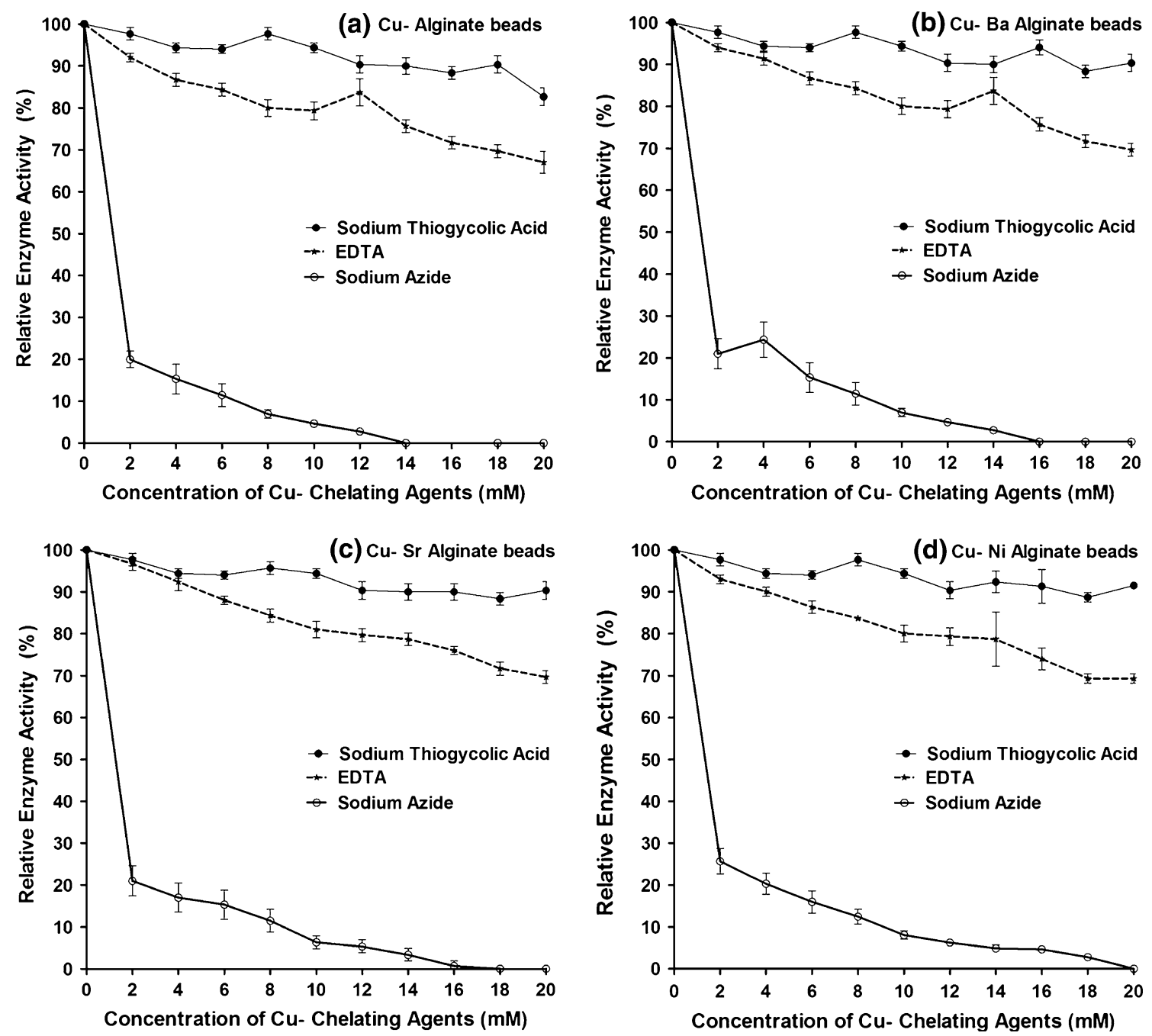

Fig. 4 Tolerance of immobilized laccase to $\mathrm{Cu}$-chelators. a $\mathrm{Cu}$-alginate beads. b $\mathrm{Cu}-\mathrm{Ba}$ alginate beads. $\mathbf{c} \mathrm{Cu}-\mathrm{Sr}$ alginate beads. d $\mathrm{Cu}-\mathrm{Ni}$ alginate beads

ous metal ions can be utilized in treating metal contaminated industrial effluents.

\section{Effect of copper chelating agents}

Laccase is a copper-dependent protein, and the presence of copper chelating agents in treatment plants usually poses a threat to its stability and enzymatic action. Also in some circumstances, the low physical stability of the beads in the presence of chelating agents can be problematical (Teerapatsakul et al. 2008). So, the effect of copper chelating agents on the activity of immobilized laccase was checked. As shown in the Fig. 4, $\mathrm{Cu}-\mathrm{Ba}$ and $\mathrm{Cu}-\mathrm{Ni}$ alginate beads retained $90 \%$ of its initial activity even in the presence of
$20 \mathrm{mM}$ EDTA and sodium thioglycolic acid, whereas $\mathrm{Cu}$ alginate beads could retain only $70 \%$ of its initial activity under the same conditions. On the other hand, sodium azide inhibited $80 \%$ of the initial activity of all the beads even at a very low concentration of $0.5 \mathrm{mM}$. The slight decrease in the tolerance by $\mathrm{Cu}$-alginate beads to the chelating agent in comparison with the combination beads may be due to the effect of copper chelating agents on the physical stability of the $\mathrm{Cu}$-alginate beads (Teerapatsakul et al. 2008). The tolerance exhibited by the immobilized laccase toward high concentrations of EDTA and sodium thioglycolic acid signifies its tolerance to some copper chelators which may be considered as an advantage in treating the industrial effluents contaminated with such chemicals. 

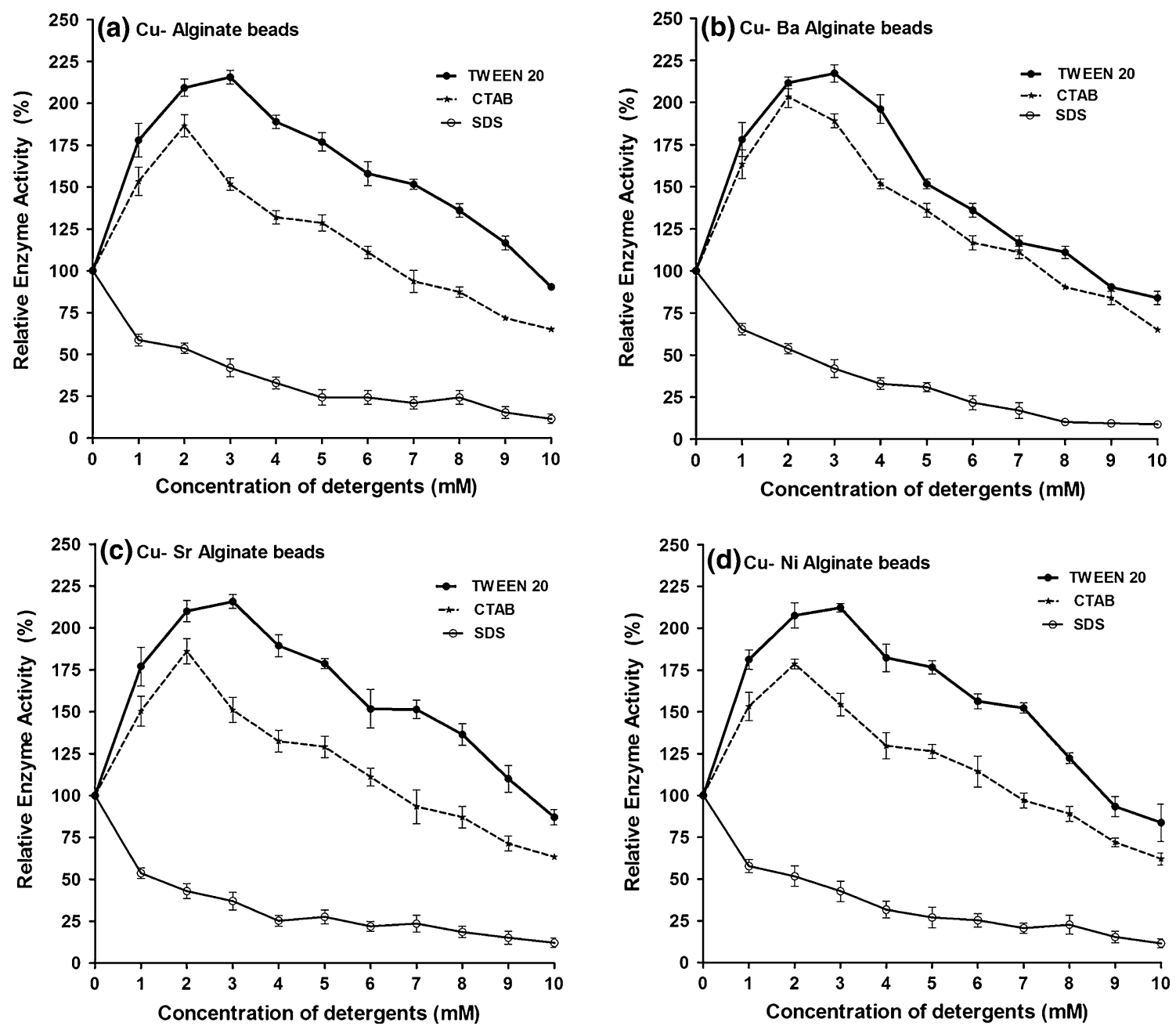

Fig. 5 Tolerance of immobilized laccase to detergents. a $\mathrm{Cu}$-alginate beads. $\mathbf{b} \mathrm{Cu}-\mathrm{Ba}$ alginate beads. $\mathbf{c} \mathrm{Cu}-\mathrm{Sr}$ alginate beads. $\mathbf{d} \mathrm{Cu}-\mathrm{Ni}$ alginate beads

\section{Effect of detergents}

Since most detergents are known to denature enzymes, their presence in treatment plants usually poses a threat to the biotreatment processes. So, the effect of detergents on the activity of immobilized laccase was checked. As shown in Fig. 5, all tested beads expressed almost a similar pattern of activity with $\mathrm{Ba}-\mathrm{Cu}$ alginate exhibiting somewhat higher activity than the rest. CTAB $(t=7.327 d f=10$, $P$ value $=0.0001)$ and Tween $20(t=8.201 d f=10$, $P$ value $=0.0001)$ significantly increased the activity of $\mathrm{Ba}-\mathrm{Cu}$ alginate beads compared to other detergents tested. A very recent study by Sharma et al. (2013) has shown moderate stability of purified laccase to surfactant, Triton X-100 and all tweens (except Tween 20), SDS and CTAB at 5 and $10 \mathrm{mM}$ concentration. Immobilized beads showed tolerance to all detergents analyzed except SDS even at a high concentration of $10 \mathrm{mM}$. Interestingly, CTAB and
Tween 20 at a concentration of 2 and $3 \mathrm{mM}$, respectively, enhanced the activity of immobilized laccase to its double and triple fold, respectively. The effect of detergents on immobilized laccase was not reported earlier. In contrast to earlier studies reported on free enzymes (Laufer et al. 2006; Sharma et al. 2013), SDS decreased the enzymatic activity of immobilized laccase at concentrations higher than $2 \mathrm{mM}$. This study for the first time demonstrates the effect of detergents on immobilized laccase. The stability exhibited by the immobilized laccase toward surfactants can be utilized in treating effluents contaminated with detergents.

In conclusion, immobilization conditions of laccase were optimized, and the sensitivity of immobilized laccase from T. viride Pers NFCCI-2745 to heavy metals, detergent and copper chelating agents was analyzed. The study was mainly undertaken because of the threat raised by the presence of heavy metals, detergents and metal chelating 
agents in the industrial effluents which act as non-competitive inhibitors/denaturing agents for several enzymes. In the present study, we found that the detergents, metal ions and $\mathrm{Cu}$-chelators did not significantly alter either the physical stability of the beads or its enzymatic activity. In addition, lower concentration of these agents significantly enhanced the activity of immobilized laccase. The concentrations and combinations of cations influenced the activity of immobilized enzyme and its yield. The immobilized $\mathrm{Cu}-\mathrm{Ba}$ alginate enzyme showed comparatively higher activity compared to the $\mathrm{Cu}$-alginate enzyme. Most of the metal ions tested enhanced laccase activity at lower concentration. Immobilized laccase retained more than $70 \%$ of its activity even in the presence of $20 \mathrm{mM}$ copper chelating agents like EDTA and sodium thioglycolic acid. Sodium azide, on the other hand, inhibited $80 \%$ of the activity of all the beads even at a very low concentration of $0.5 \mathrm{mM}$. $\mathrm{Cu}-\mathrm{Ba}$ and $\mathrm{Cu}-\mathrm{Ni}$ alginate enzyme exhibited comparatively higher tolerance than $\mathrm{Cu}$-alginate beads to EDTA and sodium thioglycolate. Tween 20 and CTAB significantly increased the activity of all the beads. These properties of the immobilized laccase may be considered and appropriately utilized in treating phenolic effluents that may contain heavy metals, detergents and certain copper chelating agents which may otherwise pose a threat to enzymatic activity.

Acknowledgments Department of Biotechnology and Microbiology, Kannur University, India, is gratefully acknowledged for the facilities provided to conduct this study.

Conflict of interest There are no conflicts of interest in the opinion given in the manuscript.

\section{References}

Abadulla E, Tzanov T, Costa S, Robra KH, Cavaco PA, Guebitz GM (2000) Decolorization and detoxification of textile dyes with a laccase from Trametes hirsuta. Appl Environ Microbiol 66:3357-3362

Aryee AN, Simpson BK (2012) Immobilization of lipase from grey mullet. Appl Biochem Biotechnol 168(8):2105-2122

Baldrian P (2006) Fungal laccases-occurrence and properties. FEMS Microbiol Rev 30:215-242

Baldrian P, Gabriel J (2002) Copper and cadmium increase laccase activity in Pleurotus ostreatus. FEMS Microbiol Lett 206:69-74

Baldrian P, in Der Wiesche C, Gabriel J, Nerud F, Zadrazil F (2000) Influence of cadmium and mercury on activities of ligninolytic enzymes and degradation of polycyclic aromatic hydrocarbons by Pleurotus ostreatus in soil. Appl Environ Microbiol 66(6):2471-2478

Brandi P, D'Annibale A, Galli C, Gentili P, Pontes ASN (2006) In search for practical advantages from the immobilisation of an enzyme: the case of laccase. J Mol Catal B Enzym 41:61-69

Champagne PP, Nesheim ME, Ramsay JA (2013) A mechanism for $\mathrm{NaCl}$ inhibition of Reactive Blue 19 decolorization and ABTS oxidation by laccase. Appl Microbiol Biotechnol 97(14):6263-6269

Couto RS, Sanroman MA, Hofer D, Gubitz GM (2004) Stainless steel sponge: a novel carrier for the immobilisation of the white rot fungus Trametes hirsuta for decolourization of textile dyes. Bioresou Technol 95:67-72

Cuoto S, Herrera JL (2006) Fungal laccases: biotechnology application. Biotechnol Adv 2:500-513

Delanoy G, Li Q, Yu J (2005) Activity and stability of laccase in conjugation with chitosan. Int J Biol Macromol 35:89-95

Divya LM, Prasanth GK, Sadasivan C (2013a) Elimination of estrogenic activity of thermal paper using laccase from Trichoderma sp NFCCI-2745. Appl Biochem Biotechnol 169:11261133

Divya LM, Prasanth GK, Sadasivan C (2013b) Potential of salt tolerant laccase producing strain of Trichoderma viride Pers NFCCI-2745 from estuary in bioremediation of phenol polluted environments. J Basic Microbiol. doi:10.1002/jobm.201200394. [Epub ahead of print]

Divya LM, Prasanth GK, Sadasivan C (2013c) Isolation of a salt tolerant laccase secreting strain of Trichoderma Sp NFCCI-2745 and optimization of culture conditions and assessing its potential in the treatment of saline industrial effluents. J Environ Sci (accepted). doi:10.1016/S1001-0742(12)60321-s

Duran N, Rosa MA, D'Annibale A, Gianfreda L (2002) Applications of laccases and tyrosinases phenoloxidases immobilized on different supports: a review. Enzyme Microb Technol 31:907993

Fukuda T, Uchida H, Takashima Y, Uwajima T, Kawabata T, Suzuki M (2001) Degradation of bisphenol A by purified laccase from Trametes villsoa. Biochem Biophys Res Commun 284:704-706

Hemmat J, Mazaheriassadi M (2013) Optimization of reactive blue 19 biodegradatin by Panerochaete chrysosporium. Int J Environ Res 7(4):957-962

Knezevic Z, Bobic S, Milutinovic A, Obradovic B, Mojovic L, Bugarski B (2002) Alginate-immobilized lipase by electrostatic extrusion for the purpose of palm oil hydrolysis in lecithin/ isooctane system. Process Biochem 38:313-318

Laufer Z, Beckett R, Minibayeva FP (2006) Co-occurrence of the multicopper oxidases tyrosinase and laccase in lichens in suborder Peltigerineae. Ann Bot 98(5):1035-1042

Lu L, Zhao M, Wang Y (2007) Immobilization of laccase by alginatechitosan microcapsules and its use in dye decolorization. World $\mathrm{J}$ Microbiol Biotechnol 23:159-166

Mayer AM, Staples RC (2002) Laccase: new functions for an old enzyme. Phytochem 60:551-565

Nayanashree G, Thippeswamy B (2014) Natural rubber degradation by laccase and manganese peroxidase enzymes of Pencillium chrysogenum. Int J Environ Sci Technol. doi:10.1007/S13762-014-0636-6

Niladevi KN, Jacob N, Prema P (2008) Evidence for a halotolerantalkaline laccase in Streptomyces psammoticus: purification and characterization. Process Biochem 43:654-660

Palmieri G, Giardina P, Bianco C, Scaloni A (1997) A novel white laccase from Pleurotus ostreatus. J Biol Chem 272:31301-31307

Palmieri G, Giardina P, Bianco C, Fontanella B, Sannia G (2000) Copper induction of laccase isozymes in the lignolytic fungus Pleurotus ostreatus. Appl Environ Microbiol 66:920-924

Peralta-Zamora P, Pereira CM, Tiburtius ERL, Moraes SG, Rosa MA, Minussi RC, Durán N (2003) Decolorization of reactive dyes by immobilized laccase. Appl Catal B Environ 42:131-144

Phetsom J, Khammuang S, Suwannawong P, Sarnthima R (2009) Copper-alginate encapsulation of crude laccase from Lentinus polychrous Lev. and their effectiveness in synthetic dyes decolorizations. J Biol Sci 9(6):573-583

Rama R, Mougin C, Boyer F, Kollmann A, Malosse C, Sigoillot J (1998) Biotransformation of benzo[a]pyrene in bench scale 
reactor using laccase of Pycnoporus cinnabrinus. Biotechnol Lett 20:1101-1104

Sharma KK, Shrivastava B, Sastry VRB, Sehgal N, Kuhad RC (2013) Middle-redox potential laccase from Ganoderma sp.: its application in improvement of feed for monogastric animals. Sci Rep 3:1299-12308

Sole M, Muller I, Pecyna MJ, Fetzer I, Harms H, Schlosser D (2012) Differential regulation by organic compounds and heavy metals of multiple laccase genes in the aquatic hyphomycete Clavariopsis aquatica. Appl Environ Microbiol 78:4732-4739

Teerapatsakul C, Abe N, Bucke C, Kongkathip N, Jareonkitmongkol S, Chitradon L (2008) Dye decolorisation by laccase entrapped in copper alginate. World J Microbiol Biotechnol 24:1367-1374

Tischer W, Kasche V (1999) Immobilized enzymes: crystals or carriers? Trends Biotechnol 17(8):326-335
Tyagi S, Kumar V, Singh J, Teotia P, Bisht S, Sharma S (2014) Bioremediation of pulp and paper mill effluent by dominant aboriginal microbes and their consortium. Int $\mathbf{J}$ Environ Res 7(4):957-962

Won K, Kim S, Kim KJ, Park HW, Moon SJ (2005) Optimization of lipase entrapment in Ca-alginate gel beads. Process Biochem 40:2149-2154

Xu F, Kulys JJ, Duke K, Li K, Krikstopaitis K, Deussen HJ, Abbate E, Galinyte V, Schneider P (2000) Redox chemistry in laccase catalysed oxidation of N-hydroxy compounds. Appl Environ Microbiol 66:2052-2056

Yinghui D, Qiuling W, Shiyu F (2002) Laccase stabilization by covalent binding immobilization on activated polyvinyl alcohol carrier. Lett Appl Microbiol 35(6):451-456 